\title{
Preface
}

I cannot forecast to you the action of Russia. It is a riddle wrapped in a mystery inside an enigma

Winston Churchill

The idea for a book about the new Russian business elite grew out of a preliminary study in 1998 of Russian business organizations and their leaders in the postperestroika era. The introduction of radical political and economic reforms by Boris Yeltsin and market-oriented members of the Russian government resulted in a dramatic transformation of Russian society. The consequence of many of these changes has been mixed, however. Certain segments of industry have profited from the new situation - among them, oil companies, some high-tech firms, and selected financial institutions. Some entrepreneurial organizations have flourished, whereas other companies in other segments ceased to exist soon after inception. At that time, each of the authors of this book was following developments in the country from their own point of interest. We decided to pool our strengths and explore the enigma together.

It has proved to be a challenge. The fact that Russia is still in the middle of a radical transformation makes any attempt to decipher Russian business leadership styles an unnerving task. Every time we, the authors of this book, visit the country, we are tremendously impressed by the astonishing changes taking place there. Deciphering the enigma that is Russia becomes even more complex because the country is also extremely diverse - having long been a melting pot of different races, religions, languages, regions and cultures. The new Russian business leaders of the first perestroika wave came from different strata of the society - Communist Party and Komsomol, academia, industry, or the black economy. However, they often exhibited similar leadership styles rooted in traditional Russian culture, as reflected in power hoarding, the manipulation of employees, and the existence of multiple standards of behavior. In the tenyear period that began in 1993, on the other hand, we saw the emergence of another group of business leaders whose success draws on their own efforts and drive rather than simply political connections. In addition it is only recently that women have started to gain a visible presence as senior executives. It is becoming obvious that there is a new post-perestroika generation of business 
leaders in Russia. Given these various developments, this book looks at both traditional and more unconventional business leaders.

Over the past five years we studied these organizations in a society in transition, and collected our findings in seven case studies, focusing on Russian leaders in different industries. Some of the companies we visited still had visible and invisible traces of a Soviet-era infrastructure and mind-set. Others had a completely new organizational structure, inspired in some ways by Western business practices, and yet still uniquely Russian. The cases are presented with commentaries in this book in roughly chronological order, allowing the reader to follow the progression of the business paradigm within Russia over a ten year period.

As we studied Russian organizations, we realized we were seeing two kinds of leaders at the top of successful companies. In the first group were 'Russian' Russians, who retained a faintly xenophobic attitude toward Western organizations. These Russians were convinced that they should move into relationships with Western partners only with great caution. They sought to build 100 per cent Russian organizations. In the other group were the 'Global' Russians, leaders who have gained respect both within the Russian business community and internationally, as they build intangible bridges over which knowledge and products can travel both to and from the West. Many of them trade actively with foreign partners, acting as both vendors and buyers of goods and services. Some of the organizations led by new-generation executives are actively pursuing foreign investment, attracting shareholders globally. Some of them are even quite idealistic (perhaps too idealistic), believing that Western management practices are the answer to all ills - and they are very disappointed when this idea proves to be wrong.

We have also noticed significant changes in the Russian workforce. As Russian business practices mature, so has the Russian labor force. There are more and more individuals with Western business education and experience. Western business ideas and concepts are included in educational curricula at universities in Russia. As the challenges of organizations become more complex, the growing corps of talented young managers may become a blessing and a curse for top executives. New ways of managing talent become necessary, and the leaders of organizations that we have studied have different, sometimes totally opposite approaches to managing their human resources. Some treat them as almost disposable commodities, while others see their people as their most important capital and treat them accordingly by investing heavily in their training and development, both in financial and emotional terms. The concept of 'human resource management' is itself new, and it was quite interesting to hear about some of the mistakes made and lessons learned by the executives we talked to. Our cases cover a wide scope of leadership styles in Russian organizations, most of them with recognizable paternalistic (or maternalistic) ropts. 
Why did we write this book? As we move more into a global economy, the need to become familiar with executive behavior in Russia is increasingly apparent. In order to work effectively with Russian organizations, it is essential for potential Western partners and shareholders to understand fully the leadership style, organizational practices, and expectations typical of both 'Russian' and 'Global' Russian business leaders. Furthermore, the identification of salient management values and attitudes becomes very timely in predicting and obtaining shareholder value when dealing with Russian organizations. A comprehension of cross-cultural differences and the corollary institutional configurations will contribute to a greater success in doing business in Russia and/or with Russians, and by extension to many of the former Soviet-bloc countries in Eastern Europe.

\section{KNOWLEDGE BASE}

This book is the result of ten years of data collection and interviews in Russia, and personal experience of conducting business in the country. Two of the coauthors are Russian; one of them spent six years leading Russian organizations, while the other has been observing and training managers in Russia for nine years. Of the non-Russian authors, one is an American who has spent most of her adult life in France. The other non-Russian spent his formative years in Holland, but since then has lived the greater part of his life in other cultures. Furthermore, apart from the diversity in the authors' cultural backgrounds, there is also diversity in organizational Weltanschauung that will be reflected in the commentary to the cases. One of the authors has a strategic orientation to organizational analysis, another is more cognitive organizational oriented, while the fourth author's orientation is more of a cross-cultural nature. And not to forget, one of the authors has more of a clinical outlook to organizational analysis. Our view is that these different orientations contribute to the richness of the book.

The book includes a survey of the literature dealing with Russian national character and Russian history. Existing data gathered during frequent visits to Russia of the Western contributors are another source of information. The conceptual material also draws on Manfred Kets de Vries' two theoretical articles: 'The anarchist within' written for Human Relations and 'Journey into the wild East' written for Organizational Dynamics. These two articles explore the ways in which the Russian national character - including leadership style and organizational practices - is embedded in its culture: the ideals, values and assumptions about life that are widely shared among its people, and that guide specific behavior patterns. Comprehending the building blocks of culture in Russia and their similarities with Western culture and management philosophy 
will help to better understand the way business leaders develop in Russian organizations. This interplay of the idiosyncrasy of the Russian culture and modern Western management approaches makes up the theoretical framework within which we analyse the organizations in the book.

Our second source of data is our open-ended interviews and observations of Russian executives occupying influential positions in their respective organizations. Russian academics participated in the writing of all the case studies. These case studies, studying different parts of Russian enterprise, form the heart of this book. In writing these case studies we have had unprecedented access to the personal background and professional development of several very successful Russian leaders. We have interviewed powerful top executives, entrepreneurs and oligarchs, whose names are familiar to many Russians and Westerners. We have included leaders from a wide range of industries: banking, oil, high-tech software, and consumer goods. We also have been collecting shorter vignettes that illustrate additional leadership styles; these we have woven into the book. Thus the book covers the whole spectrum of Russian businesses from small entrepreneurial start-ups to huge companies that influence not only the economy but also the politics of the country.

\section{INTENDED AUDIENCE}

If Russians hope to be able to operate successfully in a global economy, as their recent societal transformations suggest that they do, they must identify and adopt the most appropriate forms of management and organization. Given the explosion of East-West strategic alliances, joint ventures, acquisitions and start-ups in what was the former Soviet Union, to make these ventures work (and many have been unsuccessful) - to create effective collaborative efforts - a deep understanding is needed of differences in leadership between Russians and people from other cultures. Russia has the potential to become one of the great economies of the world. The world cannot afford to stay away.

This book will be of interest to Russians, and people working in Russia, as well as in former Soviet-bloc member countries in Eastern Europe. This interest group will be made up of academics as well as practitioners. Because the case studies are first-hand, the book allows the reader to experience a Russian organization from the inside. Such exposure will be helpful in better understanding what it means to work with Russians. Consultants, HR professionals, venture capitalists, and other businesspeople who work with Russians, or are planning to invest in Russian businesses, will appreciate both the book's in-depth analysis of culture and character, as well as the practical advice and points of view offered by the executives we profile. In addition, the book can also be used in MBA classes and executive seminars in human resource management and leadership 


\section{A ROAD MAP}

The book is divided into three parts: 'Conceptual reflections', 'Case studies and commentaries', and 'Conclusions'. The first chapter highlights a number of salient aspects of the culture and character of Russia to facilitate an informed understanding of the way Russians deal with organizations and approach leadership style. This chapter starts with a number of contextual factors concerning Russia. The inference is made that these contextual factors contribute to a number of character traits. Subsequently, the implications of Russian child-rearing and educational practices are discussed. Attention is given to the development of a 'false self' - a public self that is split from the true private self - a phenomenon that was especially prevalent during the Soviet era. Other themes explored include the role of women in Russian society, emotional expressiveness, the particularistic outlook toward other people, and Oblomovism - the tendency toward apathy and inertia. The oscillation in Russia between order and disorder is also explored. The history of destructive bureaucracy in Russia is presented as a social defense. The Czarist legacy, with its contribution to a paranoid Weltanschauung and an anarchistic streak within the culture, is reviewed. The Russians' wish for strong leadership (and the existence of paternalistic practices) is analysed. Finally, Russian attitudes toward reality testing and time are looked at.

Chapter 2 is an East-West dialogue between the Western and Russian authors of the book. This opening dialogue is an accessible introduction to leadership in general, and to organizational leadership in Russia specifically. The dialogue covers a broad panorama of issues relevant to Russia. This dialogue sets the tone for the book: it is practical and draws on comments and insights offered by Russian executives themselves, while at the same time being grounded in theory and constructs that help the reader understand not only what Russian executives do, but also why they do it.

The second part of the book includes seven case studies. In Chapter 3, 'The Bolshevik evolution', a bi-cultural Russian executive returns to Russia after a 20-year exile in France to head Groupe Danone's transformation of a Soviet icon - the Bolshevik Biscuit Factory. Drawing on his experience of French and Russian culture, the new general manager brings Bolshevik into Danone's fold, and into the 21 st century. This case study illustrates that privatized Soviet-era companies can be successfully integrated within a multinational organization - if certain precautions are taken. It shows that an Anglo-Saxon-style revolutionary change process is not always the best way to proceed in Eastern European organizations; that the commonly accepted goals of rapid change, employee empowerment and a flatter hierarchy are not necessarily appropriate in these organizations in the short-term; and that even the definitions of trust, strategy and leadership can differ according to cultural context. The challenge in this case lies 
in understanding the complexities - the lingering influence of the Soviet planned central economy, as well as the Russian culture and management systems.

Chapter 4, 'Russian Standard', is a case study about one of the first Russian entrepreneurs able to create a successful brand-management organization in the early 1990s, when entrepreneurship first became legal. It is the story of entrepreneurship in its purely Russian form, with lingering traces of the Soviet paternalism and a central command and control structure. The case describes Roustam Tariko's attempts to create a more Western organizational structure and create new businesses. It addresses issues that typically arise in new ventures and 'bricks to clicks' transformation, including: evolution from the messy start-up stage to a more professional organization; intrapreneurship and internal incubators; strategies for continued growth and diversification; and brand management and marketing - with a distinctly Russian flavor.

Chapter 5, 'Mikhail Khodorkovsky: man with a ruble', concerns the CEO of Yukos, Russia's largest oil company. This case describes the trials and tribulations of this business tycoon before he ran afoul of the state authorities. This oligarch, by 2003 the richest man in Russia and one of the richest people in the world, started his business career during Gorbachev's perestroika as a junior Komsomol (young Communists' organization) official. As head of Yukos Oil Company, Russia's largest oil and gas group, he oversaw the transformation of an unstructured asset portfolio - an amalgamation of traditional Russian organizations - into a world player in the oil markets. From the discussion he emerges as a mixture of the old-style leader, who believes that power should be concentrated at the top and tight control mechanisms should play a key role in managing his organization and, at the same time, a reborn, progressive businessman bringing transparency and Western expertise to Yukos - a company whose oil reserves now rival the largest Western organizations', making it a truly global player.

Chapter 6, 'Ice and flame: building a NYSE company in wild Russia' tells the story of a partnership between two polar opposites, a brash young American entrepreneur and a rumpled Russian academic. Together they built VimpelCom, a Russian cellular operator that grew in less than 10 years from a hypothetical concept, to a small family-like company, to a $\$ 35$ billion NYSEquoted corporation with 10 million subscribers on its nation-wide wireless networks. Each of the two founders made a unique contribution. Charismatic Dr Dmitry Zimin, the Russian scientist, transmitted the partners' vision to the organization, exciting employees with new challenges, and at the same time providing a comfort zone for them to absorb the rapid pace of growth and change in the organization. No less significantly, his knowledge of Russia's political system, contacts within the military, superior technical knowledge, and perseverance allowed him to build extremely valuable social networks outside of the company American serial entrepreneur Augie K. Fabela II initially brought 
a knowledge base, which none of its competitors could match, and assumed the role of VimpelCom's link to the rest of the world, which later expanded to the growing Russian financial sector. Fabela was the driving force behind the audacious move to take the company public - the first Russian company to be quoted on the New York Stock Exchange.

Chapter 7, 'Frontstep Russia: a high-tech start-up and survival in a new "time of troubles", describes a typical start-up, with three technically brilliant but rather naïve software specialists and computer programmers who wanted to test their entrepreneurial capabilities. After working for several months with Soviet factories, educational institutions and research organizations, the future entrepreneurs obtained Western-style management exposure working for one of the first Western-Russian joint ventures. Although this experience was an excellent learning opportunity, the entrepreneurs were left with a bitter aftertaste of the authoritarian and despotic leadership style of their first Western boss. Ten years later, the company is in a successful partnership with an American organization. The case focuses on the charismatic general director, Maria Ilyina, who has some learning of her own to do as she changes her leadership style from that of 'Aunt Masha' of the early days, to become a leader who also fulfills an architectural role within her organization. This case study proves that 'garagetype' entrepreneurship is thriving in Russia.

The case study in Chapter 8, 'Troika Dialog', centers on the activities of Ruben Vardanian, President and a co-founder of Troika Dialog, Russia's oldest investment bank. This business leader is somtimes referred to as the 'Golden Boy of Russian Capitalism'. He joined Troika in 1991 as one of the company's original associates. Under Vardanian's leadership, Troika Dialog was transformed from an office with four unpaid employees into an organization with an enviable clientele and a worldwide reputation for fair practice. In 2001 he initiated an historic deal to acquire control of Rosgostrakh, one of the postSoviet 'sleeping bears': a former insurance monopoly in the Russian Federation. After becoming president of Rosgostrakh, he was faced with the enormous challenge of transforming it into a modern financial services company.

The last case study in Chapter 9, 'World class heroes for Russia', focuses on Olga Sloutsker, the founder of WorldClass, a chain of fitness centers in Moscow. She has been described as 'one of the most colorful business women in Russia today'. The fitness industry in Russia started when Sloutsker and a partner opened a Moscow franchise of a Western fitness club. Sloutsker soon left her partners to open her own, 100 per cent Russian chain. The founding entrepreneur has created a totally Russian organization with no outside partners that has incorporated the best Western business practices. Her vision is unique: to encourage all Russians to be fit, and to make 'heroes' of them all.

In the third part of the book, in Chapter 10, we conclude by exploring a new leadership agenda for Russia. In this chapter we discuss the lessons learned. 
It is suggested that management development takes on the role of catalyst to enhance a change of mind-set concerning leadership practices in Russia. A number of propositions are put forth to create more effective work behavior. To create high performance organizations, it is essential that the entrepreneurial spirit is cultivated. Finally, the prevalence of democratic centralism as a style of directing organizations is explored in the context of the desire for strong leadership. The argument is made that for Russian organizations to become more effective, this way of decision-making - a style that became perverted in Soviet times - needs to be reframed into truly empowering leadership. A number of propositions are put forth to create more effective work behavior and high performance organizations. Observations are made on how to cultivate the entrepreneurial spirit.

We hope that by reading this book non-Russians will acquire a greater understanding of Russian national character and leadership practices, and will be more effective in Russia. We also anticipate that Russians, by reflecting on how outsiders look at their behavior and business practices, may find better ways of making their organizations successful. To Russians, this book may help reconcile two worlds: the world of a new generation expectant of the future and the Soviet world of the bureaucrat with their old values and ideas. We realize that change is difficult. But we also recall the words of the French author François de la Rochefoucauld, 'The only thing constant in life is change'. The transformation of a country is embedded in the psychology of the people. 